\title{
Trace metal concentrations in sediments from the southwest of the Iberian Peninsula
}

\author{
JULIÁN BLASCO ${ }^{1}$, TANIA GOMES ${ }^{2}$, TAMARA GARCÍA-BARRERA ${ }^{3}$, \\ ARACELI RODRÍGUEZ-ROMERO ${ }^{1}$, MARÍA GONZALEZ-REY ${ }^{2}$, \\ FERNANDO MORÁN-ROLDÁN ${ }^{3}$, CHIARA TROMIBINI, MICHAL MIOTK², \\ JOSÉ LUIS GÓMEZ-ARIZA ${ }^{3}$ and MARÍA JOAO BEBIANNO ${ }^{2}$ \\ ${ }^{1}$ Instituto de Ciencias Marinas de Andalucía (CSIC), Campus Río San Pedro, 11510 Puerto Real, Cádiz, Spain. \\ E-mail: julian.blasco@icman.csic.es \\ ${ }^{2}$ CIMA, Faculty of Marine and Environmental Sciences, University of Algarve, Campus de Gambelas, \\ 8005-139 Faro, Portugal. \\ ${ }^{3}$ Departamento Química y Ciencia de los Materiales, Facultad de Ciencias Experimentales, Universidad de Huelva, \\ Avda. Fuerzas Armadas s/n, 21071 Huelva, Spain.
}

\begin{abstract}
SUMMARY: Metal sediment concentrations (As, $\mathrm{Cd}, \mathrm{Cu}, \mathrm{Hg}, \mathrm{Ni}, \mathrm{Pb}$ and $\mathrm{Zn}$ ) in surface sediments (0 to $5 \mathrm{~cm}$ ) from 11 sampling stations in the southwest of the Iberian Peninsula (the Ria Formosa and the Guadiana River, the Ría de Huelva and the Bay of Cadiz) were determined in two seasonal periods (autumn 2006 and spring 2007). No seasonal metal concentration pattern was identified, as similar values were found in both periods. The highest concentrations of copper, zinc, lead and cadmium were reported in the Ria of Huelva area, and those of mercury and nickel in the Bay of Cadiz. The hazard potential index $\left(\mathrm{HP}_{\mathrm{iM}}\right)$ was determined to assess the potential risk associated with metal contamination $(\mathrm{Cu}, \mathrm{Cd}, \mathrm{Pb}$ and $\mathrm{Zn})$, taking into account extractable (presumed bioavailable) fractions of these metals and site-specific sediment quality values. When the $\mathrm{HP}_{\mathrm{iM}}$ is $>1$ there is risk, and according to this index Ría de Huelva is polluted whereas the Bay of Cadiz is not.
\end{abstract}

Keywords: metal, sediment, contamination, coastal zone, potential hazard, southwestern Iberian Peninsula.

RESUMEN: Concentración de metales trazas en SEdimentos del SuRoeste de la Península Ibérica. - La concentración de metales ( $\mathrm{As}, \mathrm{Cd}, \mathrm{Cu}, \mathrm{Hg}, \mathrm{Ni}, \mathrm{Pb}$ y $\mathrm{Zn}$ ) en sedimentos superficiales $(0-5 \mathrm{~cm})$ de once estaciones de muestreo del suroeste de la península Ibérica (Ría Formosa y desembocadura del río Guadiana, la ría de Huelva y la bahía de Cádiz) han sido analizados en otoño 2006 y primavera 2007. Las concentraciones de metales no han mostrado diferencias en los dos periodos. Las concentraciones más elevadas de cobre, zinc, plomo y cadmio se han encontrado en la ría de Huelva, mientras que para mercurio y níquel se han hallado en la bahía de Cádiz. Se ha definido un índice de riesgo potencial para los metales cobre, cadmio plomo y zinc, que tiene en cuenta los metales ligados a fracciones biodisponibles y los valores guías de calidad de sedimento específicos de la zona de estudio. El análisis de este índice $\left(\mathrm{HP}_{\mathrm{iM}}>1\right.$, evidencia riesgo $)$ ha mostrado que la ría de Huelva tiene un riesgo potencial asociado a estos metales, mientras que en la bahía de Cádiz no se ha observado este riesgo.

Palabras clave: metales, sedimento, contaminación, zona costera, riesgo potencial, SO Península Ibérica.

\section{INTRODUCTION}

Environmental contamination by metals is a worldwide problem. It is important to be aware of the possible effects of increasing levels of metal pollution on human health and the environment (Liao et al., 2006). Metals in marine sediments have a natural or anthropo- genic origin and the relative importance of these two sources depends on the metal and its location. Coastal ecosystems are often affected by anthropogenic metal inputs. The metals are transported from the water column to the sediments by adsorption to the fine particles in the seawater. These particles, with the adsorbed metals, settle on sediments, which act as both carriers and 
potential metal sources in aquatic environments (Theofanis et al., 2001). The fate and behaviour of the metals are influenced by the characteristics of the sediment, the mineralogical composition, the redox state, adsorption/desorption processes and physical transport. Although sediments are considered to be a sink for metals, changes in the physicochemical characteristics of the sediment (redox potential, $\mathrm{pH}$, dissolved oxygen) can lead to the remobilization of the metals to the overlying water. Furthermore, the burrowing activity of macroinvertebarte organisms can affect the fluxes of solutes and particles from sediment to water. Another source of metals for a deposit feeder is sediment ingestion, which can account for up to the $100 \%$ of the metal body burden in several deposit feeding invertebrates. Therefore, the metals become available to marine organisms, on which they can exert a toxic effect, and consequently humans can be affected through the food chain. One of the main problems of metals is their long biological half-life (Buccolieri et al., 2006). Research into metal contamination should focus on coastal areas, wetlands, salt marshes and estuaries, because these are highly productive and sensitive areas affected by the impact of anthropogenic contamination (Arellano et al., 1999; Cohen et al., 2001).

Although many studies on sediment metal concentrations have been carried out in the southwest of the Iberian Peninsula, the majority have focused on the area of Huelva (Fernández-Calinai et al., 1997; Ruiz et al., 1998; Grande et al., 2000; Borrego et al., 2002; Morillo et al., 2002; Santos-Bermejo et al., 2003). Few studies have been made on the Bay of Cadiz (Blasco et al., 2000; Ligero et al., 2002; Carrasco et al., 2003) and Portuguese coastal areas (Bebianno, 1995; Caetano et al., 2006). This study establishes the contamination levels in these coastal areas and determines the potential risk associated with metal contamination. The metal contamination ( $\mathrm{As}, \mathrm{Cd}, \mathrm{Cu}, \mathrm{Hg}, \mathrm{Ni}, \mathrm{Pb}$ and $\mathrm{Zn}$ ) analyses of surface sediments from ecologically important ecosystems (estuaries, coastal ecosystem and salt marshes) from the southwest of the Iberian Peninsula were carried out in two seasons (spring and autumn).

\section{MATERIALS AND METHODS}

\section{Study area}

The Ria Formosa is a large tidal lagoon that extends about $55 \mathrm{~km}$ along the south coast of Portugal and has a maximum width of $6 \mathrm{~km}$. A strongly branched system of creeks and channels is connected to the ocean by six outlets. The average depth is less than $3 \mathrm{~m}$. It has a water volume of approximately $31 \cdot 10^{6} \mathrm{~m}^{3}$, which is generally well mixed although occasional eutrophication problems have been reported (Newton and Mudge, 2003). The system has semidiurnal tides with $50 \%$ to $75 \%$ of the water volume exchanged during each tide. The western part of the lagoon is bounded by a heavily urbanized area surrounded by agricultural land (Ribeiro et al., 2008).
The Guadiana River estuary is located on the southern border between Portugal and Spain and is a single channel meso-tidal estuary that is $76 \mathrm{~km}$ long, 70 to $800 \mathrm{~m}$ wide and 5 to $15 \mathrm{~m}$ deep. The bottom consists of coarse material in the middle of the channel and finer particles near the margins (Fortunato et al., 2002). The estuary can be divided into three zones, low, middle and high, which have different salinity ranges: $>25$, $0.5-25$ and $<0.5$ respectively. The lower estuary can be divided into two main habitat types: salt marshes and the main river channel. The salt marshes are important wintering grounds for many bird species and nurseries for molluscs, crustaceans and fish. The Guadiana River crosses an extensive rural area that has massive sulphide deposits (Palanques et al., 1995). The estuary receives the domestic sewage of two cities located near the mouth (Chicharo et al., 2001; Domingues et al., 2005).

The Ria of Huelva is a complex system of drainage channels that separate several areas of the salt marshes so that they function as islets in the inner estuary. This system is controlled by the tidal regime and the inputs of the Rivers Odiel and Tinto, as well as two channels which exchange water directly with the open sea. Therefore, the fate and behaviour of contaminants in the Ria of Huelva are very complex. This ecosystem has three sources of contamination: the industrial sewage from more than forty chemical industries located in three areas close to the Ría de Huelva, the urban sewage of the city of Huelva and fluvial inputs from the Rivers Tinto and Odiel, which have acidic waters and high metal levels.

The Bay of Cadiz is a littoral ecosystem with an area of $33.6 \mathrm{~km}^{2}$ and an average depth of $3 \mathrm{~m}$. It is subjected to a tidal regime and $20 \%$ of its area has intertidal characteristics. From a hydrological point of view, it can be divided into four regions: the outer bay, with oceanic characteristics; the inner bay, which is greatly affected by the tides and less exposed to wave action; the amphibious bay, of tidal marshes; and the terrestrial bay, of areas that are permanently emerged. The area around the bay has a population of 400000 . The main industries located in the zone are related to shipbuilding, offshore industries and aerospace manufacturing.

\section{Sampling and sample pre-treatment}

Samples were collected in three areas of the SW Iberian Peninsula (Fig. 1) during two sampling campaigns (in late autumn 2006 and spring 2007): the Ria Formosa [the Ramalhete (RS), and Ribeira de Almargem (RDA) sampling sites] and the lower estuary of the Guadiana River [Ponte International (PI)], the Ria of Huelva [Huelva (HU), Punta Sebo (PS), Punta Umbría (PU), Canal Juan Carlos I right margin (CJC-d) and left margin (CJC-i)] and the Bay of Cadiz [Puente Zuazo (PZ), Trocadero (TR) and Rio San Pedro (RSP)]. Sediments were collected using PVC sediment cores that were $100 \mathrm{~cm}$ in length and $10 \mathrm{~cm}$ in diameter. The 

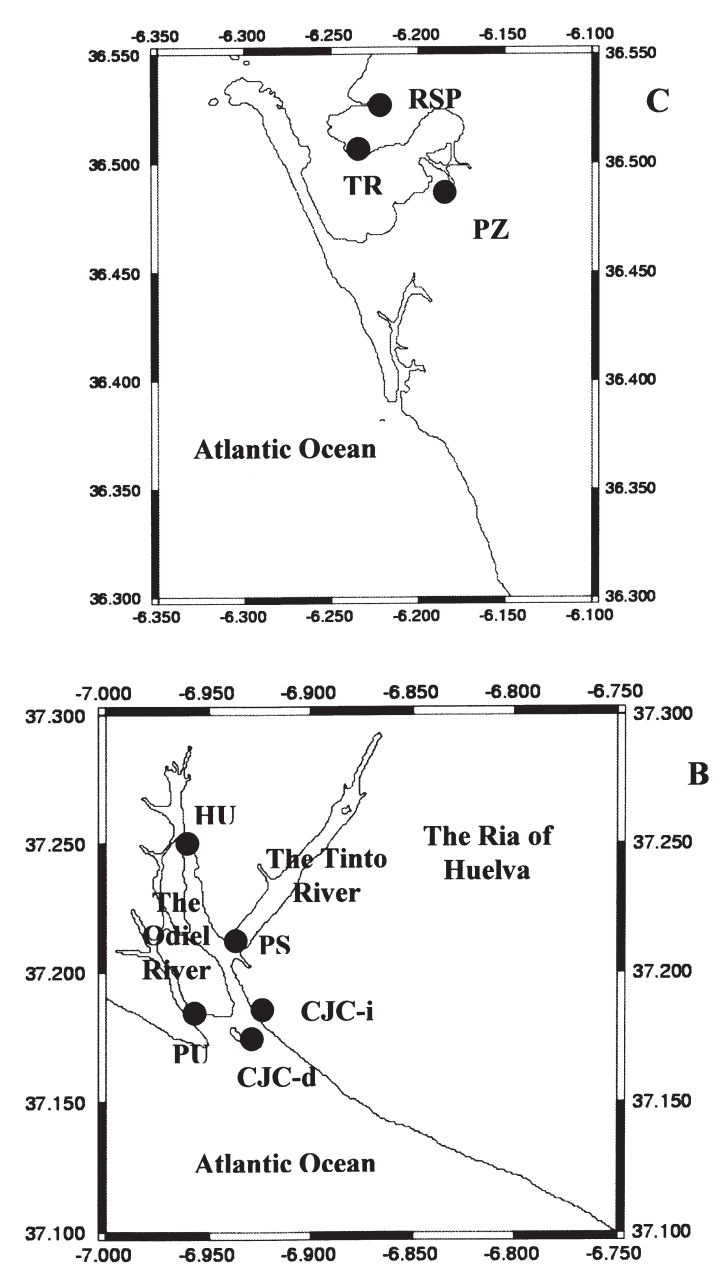

FIG. 1. - Location of sampling stations in the southwestern Iberian Peninsula.
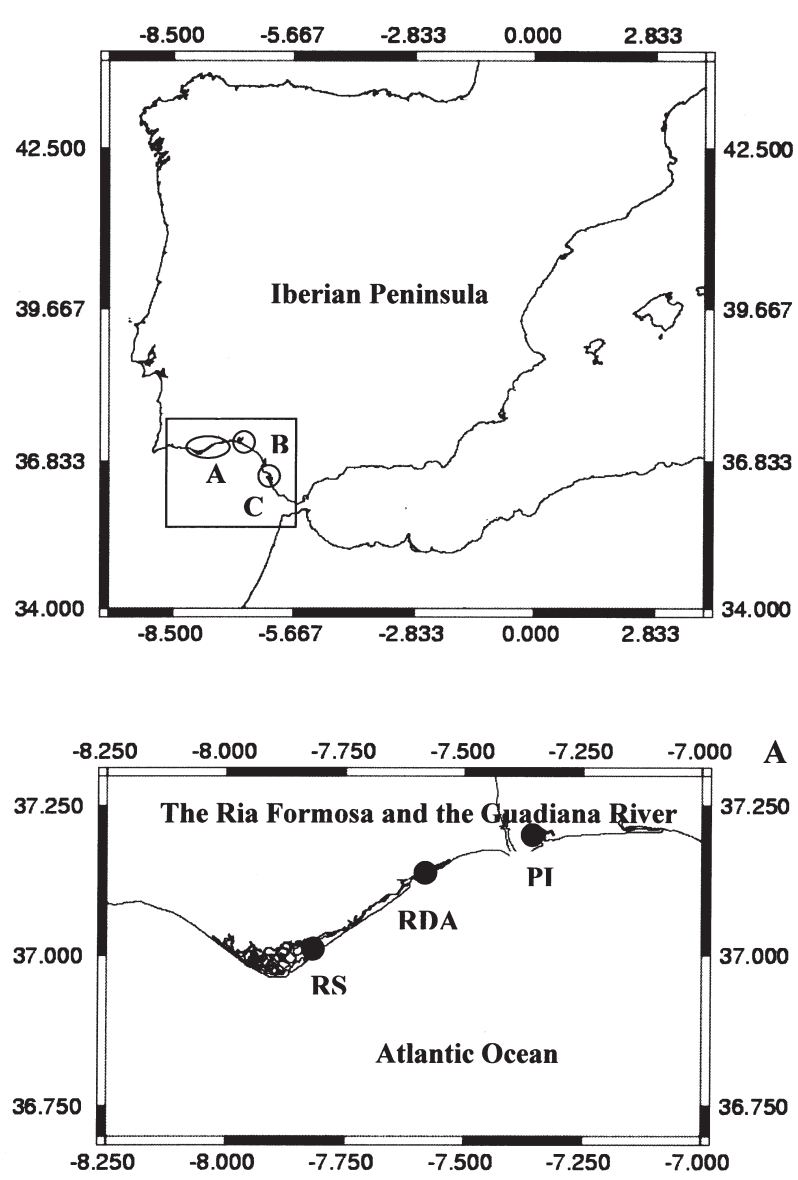

sediment cores were transported to the laboratory in a refrigerator within 3 hours of being taken and then frozen at $-18^{\circ} \mathrm{C}$ until analysis. Cores were sectioned into 5 -cm-thick samples from the surface to $30 \mathrm{~cm}$ deep. To minimize the effect of grain size on metal distribution, the analyses were carried out in the $<63 \mu \mathrm{m}$ sediment fraction. The granulometric fraction was separated from the samples with the manual wet sieving method using Nylon sieves and Milli-Q water. The sediment samples were then freeze-dried.

\section{Metal analysis}

Metal concentrations in the sediment were determined using the method described by Loring and Rantala (1992). This method consists in adding a mixture of aqua regia $\left(\mathrm{HNO}_{3} / \mathrm{HCl} 1: 3 \mathrm{v} / \mathrm{v}\right)$ and $\mathrm{HF}$ to a freezedried sediment aliquot (approx. $0.1 \mathrm{~g}$ ). The procedure was carried out in a microwave oven (CEM Mars 5) and, after acid digestion, samples were treated with boric acid to form a gelatinous precipitate of borosilicates (Bernas, 1968). Trace metal concentrations (Zn, Cd, $\mathrm{Cu}, \mathrm{Pb}, \mathrm{Ni}, \mathrm{Hg}$ and $\mathrm{As}$ ) were determined by ICP-OES or ICP-MS depending on the metal levels. For mercury, we used the cold-vapour technique or a LECO AMA 254 analyzer. The results were checked using reference material MESS-1 NRC. Good agreement was obtained between the analyzed and certified values. The results are expressed as $\mu \mathrm{g} \mathrm{g}^{-1}$ dry weight.

\section{RESULTS}

The metal concentrations $(\mathrm{Cu}, \mathrm{Zn}, \mathrm{Pb}, \mathrm{Cd}, \mathrm{Hg}, \mathrm{Ni}$ and $\mathrm{As}$ ) in surface sediments (0 to $5 \mathrm{~cm}$ ) from eleven sampling stations for the two sampling periods are shown in Figures 2 and 3.

The highest metal concentrations were found for zinc, followed by copper, lead, arsenic (data only available for the Ría de Huelva), nickel, mercury and cadmium in decreasing order (Table 1). No seasonal pattern was observed as the concentrations were similar in both seasons at the different sampling sites. The copper levels were similar in both seasons, and although in some cases there were noticeable differences between seasons depending on the sampling station (e.g. in HU the copper levels were higher in spring than in autumn, 

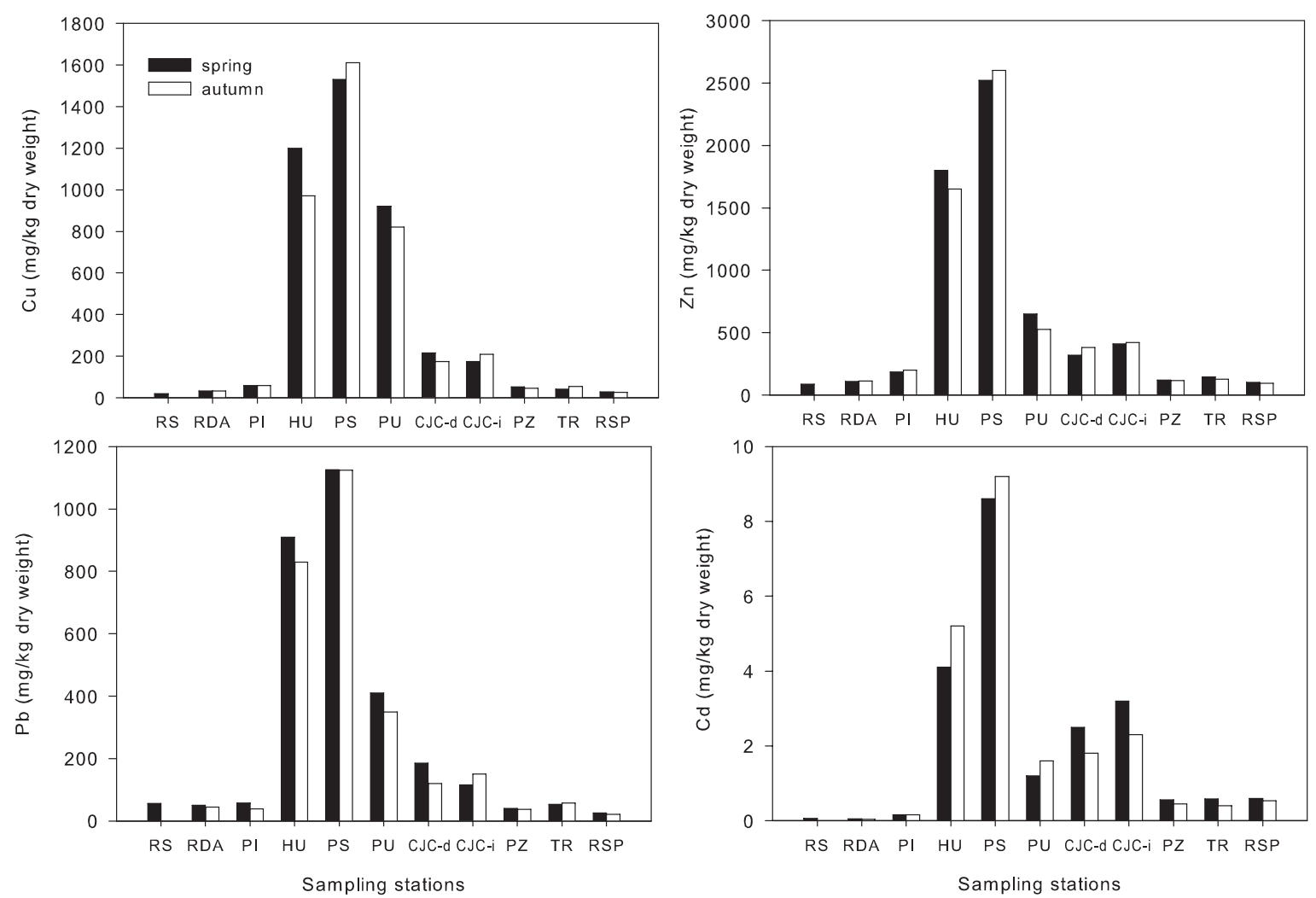

FIG. 2. - Concentrations of copper, zinc, lead and cadmium ( $\mathrm{mg} \mathrm{kg}^{-1}$ dry sediment) at the sampling stations for spring and autumn.

but in PS the copper levels were lower in spring than in autumn), in general all the analyzed metals had similar values in both seasons.

The sites in the Ría de Huelva area showed higher levels of copper, zinc, lead and cadmium than the sites at the Ría Formosa, the River Guadiana estuary and the Bay of Cadiz. In general, a gradient was observed in the Ría de Huelva, with the highest values at PS, which then decreased to the outer and inner sites (HU). The PS site is affected by the River Tinto and industrial and phosphogypsum inputs. The HU station showed the second highest concentrations of the metals mentioned above due to its location in the channel where the River Odiel drains into the estuary, which is where fresh water and seawater mix.

For mercury and nickel, the highest values were found in the Bay of Cadiz and then, in decreasing or-

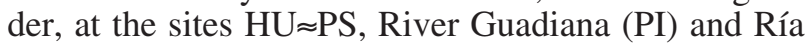
Formosa (RDA and RS). Levels of arsenic were only recorded in the Ría de Huelva.

The correlation matrix between metals, determined with the Spearman rank, showed high correlation coefficients between $\mathrm{Cd}, \mathrm{Cu}, \mathrm{Pb}$ and $\mathrm{Zn}$, which can be related to these metals having a common origin. However, $\mathrm{Ni}$ was negatively correlated with these metals, as high levels were found at the sites at the Ría Formosa, River Guadiana and Bay of Cadiz, although metal levels were generally lower in these areas than in the Ría de Huelva.

A cluster analysis was carried out to classify the
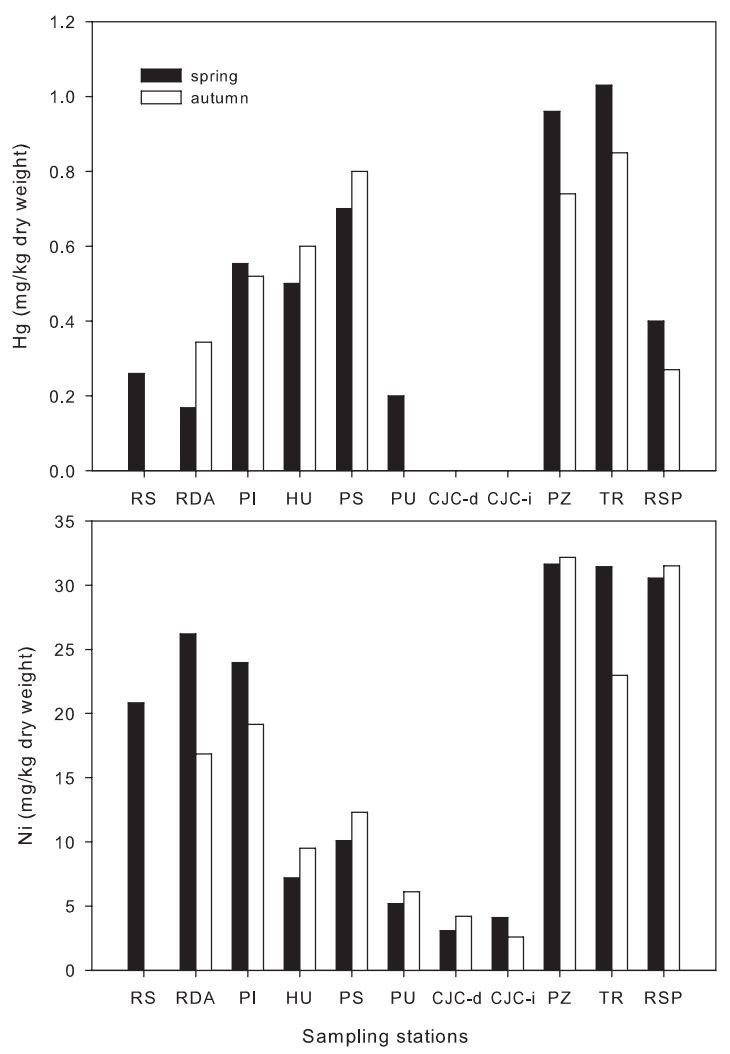

FIG. 3. - Concentrations of mercury and nickel (mg kg-1 dry sediment) at the sampling stations for spring and autumn. 
TABLE 1. - Average and range concentration for the analyzed metal at the three locations in the two sampling campaigns. Results are expressed as $\mu \mathrm{g} \mathrm{g}^{-1}$ dry weight.

\begin{tabular}{|c|c|c|c|c|c|c|}
\hline \multirow[t]{2}{*}{ Metal } & \multicolumn{2}{|c|}{ Ría Formosa and River Guadiana } & \multicolumn{2}{|c|}{ Ría de Huelva } & \multicolumn{2}{|c|}{ Bay of Cádiz } \\
\hline & Autumn & Spring & Autumn & Spring & Autumn & Spring \\
\hline $\mathrm{Zn}$ & $156(111-200)$ & $127(86-186)$ & $1115(380-2600)$ & $1140(320-2520)$ & $112(95-126)$ & $123(101-145)$ \\
\hline $\mathrm{Cd}$ & $0.10(0.04-0.16)$ & $0.09(0.05-0.16)$ & $4.02(1.6-9.2)$ & $3.9(1.2-8.6)$ & $0.47(0.41-0.52)$ & $0.58(0.56-0.60)$ \\
\hline $\mathrm{Cu}$ & $46(33-60)$ & $37(20-59)$ & 757 (175-1610) & $808(175-1530)$ & $42(26-55)$ & $41(28-52)$ \\
\hline $\mathrm{Pb}$ & $41(39-44)$ & $55(51-57)$ & $515(120-1124)$ & $549(115-1125)$ & $43(31-58)$ & $40(26-53)$ \\
\hline $\mathrm{Ni}$ & $18(17-19)$ & $24(21-26)$ & $6.9(2.6-12.3)$ & $5.9(3.1-10.1)$ & $25(21-32)$ & $31(31-32)$ \\
\hline $\mathrm{Hg}$ & $0.43(0.34-0.52)$ & $0.33(0.17-0.55)$ & $0.70(0.60-0.80)$ & $0.50(0.20-0.70)$ & $0.60(0.27-0.85)$ & $0.80(0.39-1.03)$ \\
\hline As & & & $179(45-405)$ & $178(36-380)$ & & \\
\hline
\end{tabular}

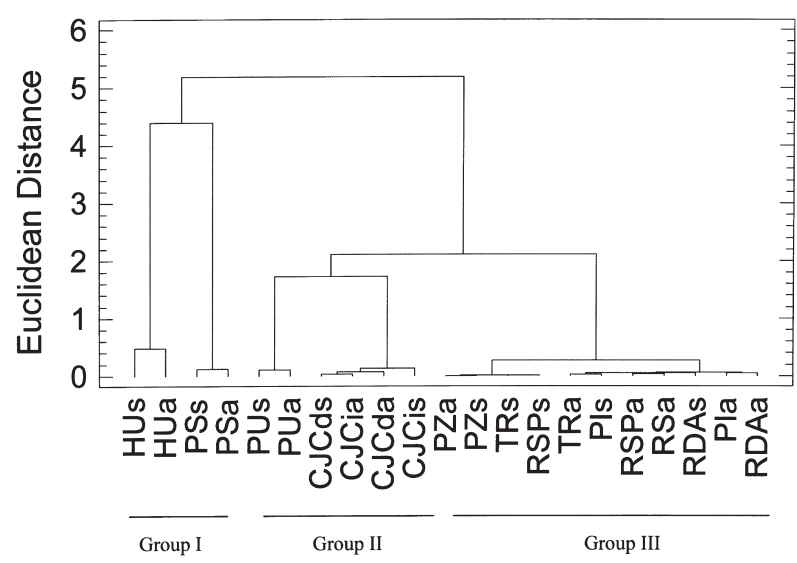

FIG. 4. - Dendrogram showing clustering of sampling sites (Group I, sampling stations HU and PS; Group II, sampling stations PU, CJCd and CJCi; Group III, PZ, TR, RSP, RA, RDA and PI).

sampling sites according to metal concentrations. The dendrogram (Fig. 4) shows three groups: the first group corresponds to the sites with high metal levels (HU and PS) in both seasons, both sampling stations in this group being affected by inputs from the Rivers Odiel and Tinto and chemical industries; the second group corresponds to the other stations from the Ría de Huelva, which are affected by the acid water from the two rivers and industrial chemical waste, but the outer positions of the stations means that the freshwater mixes with seawater; finally, the third group corresponds to the stations from the Ría Formosa, the River Guadiana and the Bay of Cadiz, which have a generally low or moderate level of contamination.

To calculate the risk associated with metal sediment contamination, we defined a hazard potential index $(\mathrm{HPi}$ ) for a metal $\mathrm{M}$, as:

$$
H P i_{M}=\frac{[M] \sum_{i=1}^{n} F i}{S Q V_{M}}
$$

where $[\mathrm{M}]=$ metal concentration; $F_{i}=$ sequential extraction fraction expressed as the sum of the percentage for the three fractions of the BCR procedure or the first four fractions of the Tessier procedure (Tessier et al., 1979) divided by 100 (in our calculations we employed the first four fractions of the Tessier approach for these ecosystems); and $\mathrm{SQV}_{\mathrm{M}}=$ the sediment quality value for each metal.

A general hazard potential index for the metal load of the sediment can been calculated as:

$$
H P i_{M L}=\frac{\sum_{j=1}^{n}\left[M_{j}\right] \sum_{i=1}^{n} F i}{S Q V_{M j}}
$$

Table 2 shows the results for four individual metals $(\mathrm{Zn}, \mathrm{Cd}, \mathrm{Cu}$ and $\mathrm{Pb}$ ). Due to the lack of specific information for sequential extraction of sediment samples, data from scientific literature on sediments of these areas were employed (Sáenz et al., 2003). This information is not available for the Ria Formosa and the Guadiana, so we preferred not to include these results in the table due to the high uncertainty associated with these indices.

The $H P i_{M}$ ranged between 1.2 and 3.6 for $\mathrm{Pb}$ and $\mathrm{Cu}$ for the Ria of Huelva and between 0.07 and 0.34 for $\mathrm{Cu}$ and $\mathrm{Cd}$, respectively, in the Bay of Cadiz. We used SQVs for highly polluted ecosystems (Choueri et al., 2009), which ensures that there are no false negatives. Values over one indicate highly polluted ecosystems, whereas values below one, using the SQVs for nonpolluted ecosystems, show that that the ecosystem is

TABle 2. - Average concentration of $\mathrm{Zn}, \mathrm{Cd}, \mathrm{Cu}$ and $\mathrm{Pb}$ in the Ría de Huelva (RHU) and the Bay of Cadiz (BC) and $H P i_{M}$ calculated using the sum of the first four fractions $\left(\sum_{i=1}^{n} F i\right)$ of the Tessier approach (Sáenz et al., 2002) and SQVs (Choueri et al., 2009). The HPi $i_{M}$ index shows the range using SQVs corresponding to values for not polluted and highly polluted.

\begin{tabular}{lcccccccc}
\hline Metal & $\begin{array}{c}\text { Average concentration } \\
(\mathrm{RHU})\end{array}$ & $\sum_{i=1}^{n} F i$ & $\begin{array}{c}H P i_{M} \\
\left(\mathrm{RHU}^{2}\right)\end{array}$ & $\begin{array}{c}\text { Average concentration } \\
(\mathrm{BC})\end{array}$ & $\sum_{i=1}^{n} F i$ & $\begin{array}{c}H P i_{M} \\
(\mathrm{BC})\end{array}$ & $\mathrm{SQV}(\mathrm{a})$ & $\mathrm{SQV}(\mathrm{b})$ \\
\hline $\mathrm{Zn}$ & 1128 & 76 & $2.4-6.2$ & 118 & 35 & $0.11-0.30$ & 360 & 138 \\
$\mathrm{Cd}$ & 3.96 & 87 & $2.8-5.3$ & 0.53 & 77 & $0.34-0.63$ & 1.20 & 0.65 \\
$\mathrm{Cu}$ & 783 & 77 & $3.6-29$ & 42 & 28 & $0.07-0.56$ & 169 & 21 \\
$\mathrm{~Pb}$ & 532 & 23 & $1.2-5.6$ & 42 & 50 & $0.21-0.9$ & 99 & 22 \\
\hline
\end{tabular}

* SQV Gulf of Cadiz (Choueri et al., 2009) (a) correspond to not polluted and (b) correspond to values above highly polluted. 
TABLE 3. - Average concentration in sediment from the three coastal zones and background values for the Ría de Huelva, Bay of Cadiz and average shale composition. The results are expressed as $\mu \mathrm{g} \cdot \mathrm{g}^{-1} \mathrm{dry}$ weight.

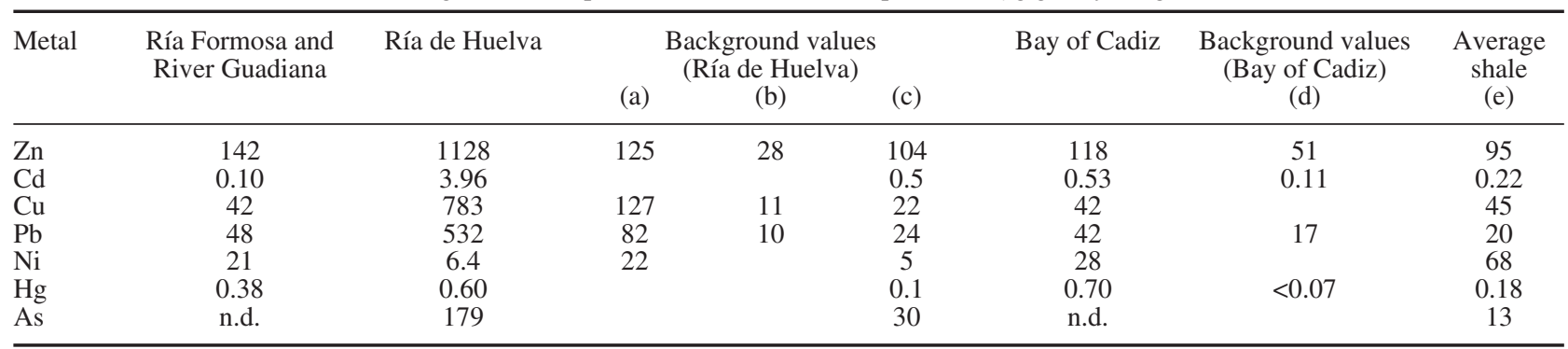

(a) Santos-Bermejo et al. (2003); (b) Borrego et al. (2002); (c) Fernández-Caliani et al. (1997); (d) Ligero et al. (2002); (e) Luoma and Rainbow (2008).

not affected by these metals. We found that the Ría de Huelva ecosystem is heavily affected by metal contamination, whereas the Bay of Cadiz is not affected. The $H P i_{M L}$ corresponds to the sum of all the metals, and had a value of 10 for the Ría de Huelva and 0.73 for the Bay of Cadiz. This index can be used as an initial tool for classifying areas impacted by metal contamination.

\section{DISCUSSION}

Sediments are recognized as sinks for many contaminants discharged into surface waters due to the adsorption processes of particulate matter, which then settles on the sediment. The southwest of the Iberian Peninsula is affected by metal contamination processes due to mining, industry and urban activities, and coastal ecosystems from these zones have metal inputs from a variety of sources.

The recent impact of anthropogenic activities can be assessed by measuring the metal concentrations in surface sediment, although the background values should be subtracted from the total metal concentration. Using average shale is common (Turekian and Wedephol, 1961) for calculating a geocumulation index $\left(\mathrm{I}_{\mathrm{geo}}\right)$ (Müller, 1981). However, as the natural geology can differ from the average shale, these calculations can produce misleading results. Different background values have been reported for the ecosystems in this study (Table 3), which means that the enrichment factor $\left(\mathrm{EF}_{\mathrm{M}}=\mathrm{C}_{\mathrm{sM}} / \mathrm{C}_{\mathrm{bM}}\right)$, defined as the ratio of the surface sediment metal concentration $\left(\mathrm{C}_{\mathrm{sM}}\right)$ to the background values $\left(\mathrm{C}_{\mathrm{bM}}\right)$, can vary greatly depending on the background values selected. It is clear that the use of average shale can only be considered as an initial approach when the lack of data means that sitespecific values cannot be used. For the sediments collected in the Ría Formosa and the River Guadiana no site-specific values were found and the use of average shale can lead to biased results and underestimations of the contaminant inputs. However, when several backgrounds are available, the most appropriate option is to use the most conservative data to avoid underestimating the contamination events. Therefore, to calculate the $\mathrm{EF}_{\mathrm{M}}$ in the Ría de Huelva we used the background values reported by Borrego et al. (2002). According to these, the $\mathrm{EF}_{\mathrm{M}}$ values ranged between 1.3 for nickel and 71 for copper. The low $\mathrm{EF}_{\mathrm{Ni}}$ value for nickel is because there is no pollution source for this metal (Morillo et al., 2002). In the Bay of Cadiz, the $\mathrm{EF}_{\mathrm{M}}$ ranged between 2.3 for zinc and 10 for mercury, although the background values were not available for several metals. If background concentrations of the Bay of Cadiz were used to calculate the $\mathrm{EF}_{\mathrm{M}}$ for the Ría Formosa and the River Guadiana, these ranged between 1.0 for cadmium and 5 for mercury.

The high metal contamination in the Ría de Huelva is caused by sediment contributions from the Rivers Tinto and Odiel and from the industrial activity on the estuary banks (Borrego et al., 2002). The sediment inputs correspond to fine-grained sediment enriched in sulphide-associated metals (Fernández-Caliani et al., 1997). This pattern is evident for the HU and PS sites located close to the mouth of the two rivers. $\mathrm{Cu}$ and $\mathrm{Zn}$ are of fluvial origin, whereas As is associated with industrial wastes (Grande et al., 2000). Sediment metal transport has been reported to be a source of metal for the inner shelf (Fernández-Caliani et al., 1997).

In the Bay of Cadiz, the $\mathrm{EF}_{\mathrm{Hg}}$ values close to 10 evidence the mercury input in the ecosystem, which has been observed from the beginning of the twentieth century, when this metal began to increase in the ecosystem (Ligero et al., 2002). Although cadmium had an $\mathrm{EF}_{\mathrm{Cd}}$ that indicates a recent input, it is difficult to establish the temporal evolution of this metal because diffusion processes and affinity with fine-grained sediment and organic matter can disturb the sediment profile concentrations (Ligero et al., 2002).

For the Ría Formosa and River Guadiana, the values recorded for metals in the sediments are in the same range as those reported by Bebianno (1995) and Caetano et al. (2006), indicating that there are similar levels of contamination. The lack of temporal series of metal concentrations or dated sediment profiles makes it difficult to establish the evolution of contamination. In the Guadiana River the process of sediment transport can affect metal levels in sediments, so during the peak flood process the metal content decreases significantly (Caetano et al., 2006). Although the River Guadiana sediments are less contaminated than the River Tinto-Odiel sediments, they have been reported to be 
the main source of sediment and metal contamination in the northern Gulf of Cadiz (Gonzalez et al., 2007).

Metal partitioning can be useful as an initial tool for modelling metal bioavailability and the potential risk for ecosystems. Several authors have determined the metal distribution pattern using sequential extraction procedures for the Ría de Huelva, salt marsh and Bay of Cadiz areas (Izquierdo et al., 1997; Usero et al., 1998; Morillo et al., 2002; Sáenz et al., 2003). In the Bay of Cadiz, metals are generally associated with the residual fraction, with the exception of lead. However, in the Ría de Huelva area, copper, cadmium and zinc are in the mobile phase and lead and nickel in the residual fraction (Morillo et al., 2002). The diffusive flux of $\mathrm{Cu}$ in this area showed the high concentration of this metal and its extractability and therefore presumed bioavailability (Blasco et al., 2000).

We mainly used sediment quality values (SQVs) to assess the status of contaminated sediment, but the results can vary greatly depending on the values used (Chapman et al., 1999). Although SQVs have this drawback, they are employed in the context of a tiered strategy for ecological risk assessment; they should always be applied with care and cannot be employed for regulatory purposes (Chapman and Mann, 1999). Further development of this approach should take into account the factors that affect bioavailability and toxicity.

Using only those metals associated with fractions which can be remobilized and enter the aquatic ecosystems is an improvement over using total sediment metal concentrations (Riba et al., 2002; Sáenz et al., 2003), including metals belonging to the lattice structure of the sedimentary material that are not available for organisms. The $H P i_{M}$ allowed zones to be classified according to the effect associated with each metal or the total metal load $\left(H p i_{M L}\right)$. Although these indices do not distinguish the origin of the metal because the natural source and anthropogenic or post-deposition redistribution are not separated, the total metal load, index should be used as an initial tool because the same index can be obtained when the index of a metal is very high and the other metals have values below one, or if all the metals or some of them have values above one. Both indices can be employed using the average concentration of one area or specifically for each sampling station. However, SQVs are obtained for the correlation between effect and total metal concentration (DelValls and Chapman, 1998) and if bioavailability is not taken into account the index can have higher values. SQVs are affected by uncertainty because benchmark values for large coastal ecosystems involve considering that metal bioavailability is similar for areas with different sediment geochemistry. Recently, Hewitt et al., (2009) pointed out the need to increase the ecological significance of sediment contamination guidelines by taking into account community analysis measurements, such as field-based species sensitivity distributions and multivariate models, to ensure environmental protection.

\section{ACKNOWLEDGEMENTS}

We would like to thank the Interreg III-A Programme for funding the projects RED CONTAMAR and PROTEBIOMAR and CSIC and FCT for providing funds for the project PT2007PT0040.

\section{REFERENCES}

Arellano, J.M., J.B. Ortiz, D. Capeta Da Silva, M.L. Gonzalez De Canales, C. Sarasquete and J. Blasco. - 1999. Levels of copper, zinc, manganese and iron in two fish species from salt marshes of Cadiz Bay (southwest Iberian Peninsula). Bol. Inst. Esp. Oceanogr., 15: 485-488.

Bebianno, M.J. - 1995. Effects of pollutants in the Ria Formosa lagoon, Portugal. Sci. Total Environ., 171: 107-115.

Bernas, B. - 1968. A new method for decomposition and comprehensive analysis of silicates by atomic absorption spectrometry. Anal. Chem., 40: 1682-1686.

Blasco, J., V. Sáenz and A. Gomez-Parra. - 2000. Heavy metal fluxes at the sediment-water interface of three coastal ecosystems from south-west of the Iberian Peninsula. Sci. Total Environ., 247: 189-199.

Borrego, J., J.A. Morales, M.L. de la Torre and J.A. Grande. - 2002. Geochemical characteristics of heavy metal pollution in surface sediments of the Tinto and Odiel river estuary (southwestern Spain). Environ. Geol., 41: 785-796.

Buccolieri, A., F. Italiano, A. Dell'Atti, G. Buccolieri, L. Giotta, A. Agostiano, F. Milano and M. Trotta - 2006. Testing the photosynthetic bacterium Rhodobacter sphaeroides as heavy metal removal tool. Ann Chim., 96: 195-203

Caetano, M., C. Vale and M. Falcao. - 2006. Particulate metal distribution in Guadiana estuary punctuated by flood episodes. Est. Coast. Shelf Sci., 70: 109-116.

Carrasco, M., J.A. López-Ramírez, J. Benavente, F. López-Aguayo and D. Sales. - 2003. Assessment of urban and industrial contamination levels in the bay of Cádiz, SW Spain. Mar. Pollut. Bull., 46: 335-345.

Chapman, P.M., F. Wang, W.J. Adams and A. Green. - 1999. Appropriate applications of sediment quality values for metals and metalloids. Environ. Sci. Technol., 33: 3937-3941.

Chapman, P.M. and G. . Mann. - 1999. Sediment quality values (SQVs) and ecological risk assessment (ERA). Mar. Pollut. Bull., 38: 339-344.

Chicharo, M.A., L.M. Chicharo, H. Galvao, A. Barbosa, M.H. Marques, J.P. Andrade, E. Esteves, C. Miguel, C. Gouveia and C. Rocha. - 2001. Status of the Guadiana River (south Portugal) during 1996 to 1998: an ecohydrological approach. Aquat. Ecosys Health., 4: 73-90.

Choueri, R.B., A. Cesar, D.M.S. Abessa, R.J. Torres, R.D. Morais, I. Riba, C.D.S. Pereira, M.R.L. Nascimento, A. Mozeto and T.A. DelValls. - 2009. Development of site-specific sediment quality guidelines for North and South Atlantic littoral zones: Comparison against national and international sediment quality benchmarks. J. Hazard. Mat., 170: 320-331.

Cohen, T., S. Hee and R. Ambrose - 2001. Trace metals in fish and invertebrates of three California coastal wetlands. Mar. Pollut. Bull., 42: 232-242.

DelValls, T.A. and P.M. Chapman. - 1998. Site-specific sediment quality values for the Gulf of Cadiz (Spain) and San Francisco Bay (USA) using the sediment quality triad and multivariate analysis. Cienc. Mar., 24: 313-336.

Domingues, R., A. Barbosa and H. Galvao. - 2005. Nutrients, light and phytoplankton in a temperate estuary (the Guadaiana, southwestern Iberia). Est. Coast. Shelf Sci., 64: 249-260.

Fernández-Caliani, J.C., F. Ruiz Muñoz and E. Galán. - 1997. Clay mineral and heavy metal distributions in the lower estuary of Huelva and adjacent Atlantic shelf, SW Spain. Sci. Total Environ., 198: 181-200.

Fortunato, A., L. Pinto, A. Oliveira and J. Ferreira. - 2002. Circulation and salinity intrusion in the Guadiana estuary. Thalassas, 18: 43-65

Gonzalez, R., M.F. Araújo, D. Burdloff, M. Cachao, J. Cascalho, C. Corredeira, J.M.A. Dias, C. Fradique, J. Ferreira, C. Gomes, 
A. Machado, I. Mendes and F. Rocha. - 2007. Sediment and pollutant transport in the northern Gulf of Cadiz: a multi-proxy approach. J. Mar. Systems., 68: 1-23.

Grande, J.A., J. Borrego and J.A. Morales. - 2000. A study of heavy metal pollution in the Tinto-Odiel estuary in southwestern Spain using factor analysis. Environ. Geol., 39: 1095-1101.

Hewitt, J.E., M.J. Anderson, C.W. Hickey, S. Kelly and S.F. Trush. - 2009. Enhancing the ecological significance of sediment contamination guidelines through integration with community analysis. Environ. Sci. Technol., 43: 2115-2123.

Izquierdo, C., J. Usero and I. Gracia. - 1997. Speciation of heavy metals in sediment from salt marshes on the southern Atlantic Coast of Spain. Mar. Pollut Bull., 34: 123-128.

Liao, V.H.C., M.T. Chien, Y.Y. Tseng, and K.L. Ou. - 2006. Assessment of heavy metal in contaminated sediments and soils using green fluorescent protein-based bacterial biosensors. Environ. Pollut., 142: 17-23.

Ligero, R.A., M. Barrera, M. Casas-Ruiz, D.Sales and F. LópezAguayo. - 2002. Dating of marine sediments and time evolution of heavy metal concentrations in the Bay of Cádiz, Spain. Environ. Pollut., 118: 97-108.

Loring, D.H. and R.T.T. Rantala. - 1992. Manual for the geochemical analyses of marine sediment and suspended particulate matter. Earth Sci. Rev., 32: 235-283.

Luoma, S.N. and P.S. Rainbow. - 2008. Metal Contamination in Aquatic Environments, Science and Lateral Management. Cambridge, Cambridge University Press

Morillo, J., J. Usero and I. Gracia. - 2002. Partitioning of metals in sediments from the Odiel River (Spain). Environ. Int., 28: 263-271.

Müller, G. - 1981. Die Schwermetalle in den sedimenten des Neckars und seiner Nebeflusse: eine Bestandsandnahme. Chem. Zeit., 105: 157-164.

Newton, A. and S. Mudge. - 2003. Temperature and salinity regimes in a shallow, mesotidal lagoon, the Ria Formosa, Portugal. Est. Coast. Shelf Sci., 57: 73-85.

Palanques, A., J. Diaz and M. Farran. - 1995. Contamination of heavy metals in suspended and surface sediment of the Gulf of
Cadiz (Spain): the role of sources, currents pathways and sinks. Oceanol. Acta., 18: 469-477.

Riba, I., T.A. DelValls, J.M. Forja and A. Gómez-Parra. - 2002. Influence of the Aznalcóllar mining spill on the vertical distribution of heavy metals in sediments from the Gualdalquivir estuary (SW. Spain). Mar. Pollut. Bull., 44: 39-47.

Ribeiro, J., C. Monteiro, P. Monteiro, L. Bentes, R. Coelho, J.M.S Gonçalves, P.G. Linoi and K. Erzini. - 2008. Long-term changes in fish communities of the Ria Formosa coastal lagoon (southern Portugal) based on two studies made 20 years apart. Est. Coast. Shelf Sci., 76: 57-66.

Ruiz, F., M.L. González-Regalado, J. Borrego, J.A. Morales, J.G. Pensón and J.M. Muñoz. - 1998. Statigraphic sequence, elemental concentrations and heavy metal pollution in Holocene sediments from the Tinto-Odiel estuary, southwestern Spain. Environ. Geol., 34: 270-278.

Sáenz, V., J. Blasco and A. Gomez-Parra. - 2003. Speciation of heavy metals in recent sediments of three coastal ecosystems in the Gulf of Cadiz, southwest Iberian Peninsula. Environ. Toxicol. Chem., 22: 2833-2839.

Santos-Bermejo, J.C., R. Beltrán and J.L. Gómez-Ariza - 2003. Spatial variations of heavy metals contamination in sediments from Odiel River (Southwest Spain). Environ. Int., 29: 69-77.

Tessier, A., P.G.C. Campbell and M. Bisson. - 1979. Sequential extraction procedure for the speciation of particulate trace metals. Anal. Chem., 51: 844-850.

Theofanis, Z.U., S. Astrid, G. Lidia and W.G. Calmano. - 2001 Contaminants in sediments: remobilization and demobilization. Sci. Total Environ., 266: 195-202.

Turekian, K.K. and K.H. Wedepohl. - 1961. Distribution of the elements in some major units of the earth's crust. Bull. Geol. Soc. Am., 72: 175-192.

Usero, J., M. Gamero, J. Morillo and I. Gracia. - 1998. Comparative study of three sequential extraction procedures for metals in marine sediments. Environ. Int., 24: 487-496.

Received November 1, 2008. Accepted July 30, 2010.

Published online November 13, 2010. 